\title{
Managing Formal Organizations in the $21{ }^{\text {st }}$ Century: A Critique of Fredrick Taylor's Scientific Management
}

\section{Theory}

\author{
Olu Awofeso \\ Department of Political Science \\ Obafemi Awolowo University, Ile-Ife, Nigeria
}

Received: September 25, 2019 Accepted: October 14, 2019 Published: December 3, 2019

doi:10.5296/jpmr.v5i2.15970 URL: https://doi.org/10.5296/jpmr.v5i2.15970

\begin{abstract}
Fredrick Taylor is popularly acknowledged as the father of the scientific management theory in the literature. As a strand of the classical theory of organization, the scientific management aimed at ensuring efficiency, standardization of job performance and discipline in complex organizations. When applied to bricklaying, shoveling, and metal cutting by Taylor, the scientific management approach proved to be very efficient and highly productive. Despite its remarkable success in these organizations, the scientific management has been subjected to series of criticism by scholars and authors alike. The study rely on secondary source of data to engage in a continuous academic scrutiny on the efficacy of the scientific management theory, especially, in modern organizations. The paper critically assesses the relevance or otherwise, of the scientific management theory in the $21^{\text {st }}$ century.
\end{abstract}

Keywords: Fredrick Taylor, management, organization, scientific management

\section{Introduction}

Organization theories consist of three major approaches, namely: the classical, the neo-classical, and the modern theories of organization. The classical theory of organization is of three strands which include, the Bureaucracy, popularized by Marx Weber (1862 - 1920), the Administrative Management Theory, pioneered by Henri Fayol (1841-1925), and the Scientific Management Theory, fathered by Fredrick Taylor (1856-1915). The three streams of classical theory of organization are collectively referred to as the Mechanistic Theory which takes the structural-functional approach to the study of organization. Organization, when viewed from this perspective, is characterized by "impersonality, inflexibility, division of work, hierarchy and efficiency" (Tyagi, 2004: III). The classical approach contributions to the 
advancement of management theory notwithstanding, its greatest challenge was its anti-human posture and consequently been described as "organization without human face".

The neo-classical theory of organization extended the frontier of the classical approach by simply adding a human dimension to organization management. The approach, otherwise referred to as the human relations movement, was able to unfold the importance of human element, especially, as individual and in group forms, to organizational efficiency through several psychologically based and human centered experiments. Modern management techniques and skills used in organizations today are predominantly the product of extensive researches on motivation, leadership and communication theories, as well as decision-making studies, all of which are offshoot of the neo-classical theory of organization.

The modern theory of organization is also referred to as the systems approach to organization. Unlike the classical and the neo-classical theories, which conceive of organization as close entity, the systems approach sees the organization as an open entity which interacts with its environment and adapts to changes from the environment. Thus, as an open entity, the organization influences, and its influenced by the environment. The modern approach provides a multi-factoral analysis to organizational behavior and posits that organization is situationally determined, such that, a principle or technique that worked in one organization, may not work in another organization of similar characteristics. A manager is therefore expected to use his initiative with the application of situational approach.

In light of the existing theories of organization, the paper scrutinizes the contributions of Taylor's scientific management theory and determines its relevance or otherwise, in modern organizations.

\section{On the Concept of Management and Organization}

\subsection{Management}

Management as a concept has been variedly defined by different authors and scholars. Harold Koontz (1909-1984) for instance, defines management as "the art of getting things done through others and with formally organized groups". Mary Parker Follett (1868-1933) on the other hand, refers to management as "the art of getting things done through people". Management, according to George R. Terry (1877-1955) "is a distinct process consisting of planning, organizing, actuating and controlling, utilizing in each both science and art, and followed in order to accomplish pre-determined objectives". The definitions of management as given by these scholars and many others, clearly unveils that management in the words of Louis Allen is all about "what a manager does" or the functions performed by the chief executive of an enterprise in order to accomplish the organization's objectives, both efficiently and effectively.

This presupposes that management is essentially a goal oriented activity targeted for accomplishment through cooperation and collaboration with others. Management, in this regard has also been defined by Koontz and O'Donnell as "the creation and maintenance of an internal arrangement in an enterprise where individuals working together in groups can perform efficiently and effectively towards the attainment of group goals". Therefore, and in 
the words of Henri Fayol, "to manage is to forecast and to plan, organize, to command, to coordinate and to control" and of course, to perform many other functions identified by several other management scholars.

Fredrick Taylor's perception of the concept of management is not at variance with the definitions of management cited by scholars above. Taylor for instance, "views management as the process of getting things done by people operating independently or as groups" (Sapru, 2013:114). The central thrust of Taylor's scientific management thesis was how to ensure industrial harmony through cooperation between management and workers such that both will reap the benefits of efficiency and effectiveness which according to him are increased output at low cost and high wage respectively. Taylor at another level emphasizes the need for management to live up to its responsibility by doing the work of planning, organizing, controlling, determining method and the likes expected of the chief executive and allow workers to carry out those instructions having been taught how to do them.

\subsection{Organization}

Two major perspectives on the definition of organization can be identified from the copious literature on the concept of organization. The first consists of those that perceive organization as structural entity comprising of units with power and authority to carry out specified functions aimed at achieving pre-determined goals. To this group of scholars, organization has been variedly defined as: "the formal structure of authority through which work sub-division are arranged, defined and coordinated for defined objective" (Gullicks, 1937); "the structure developed for carrying out the task entrusted to the chief executive and his administrative subordinates in government" (Marx, 1946:140) and "the structuring of individuals and functions into productive relationship" (Pfiffer, 1960).

Expressing the viewpoints of the second school of thought on the concept of organization, Hebert Simon (1976:xvii) defines organization as "the complex pattern of communication and relationship in a group of human being". Closely in tune with this school of thought are definitions of organization by other authors such as: "organization is the form of every human association for the attainment of a common purpose" (Mooney, 1947); "the arrangement of personnel for facilitating the accomplishment of some agreed purposes through the allocation of functions and responsibilities" (Gaus, 1947) and "the pattern of relationships between person in enterprise, so contrived as to fulfill the enterprise's function" (Gladden, 1962).

The two schools of thought on the definition of organization represent the viewpoints of the classical or traditional and the behavioural or humanistic scholars respectively. While the classical writers argue that a well-defined chart or structure combined with strict adherence to rules and procedures are major requirements for organizational efficiency, the behaviouralists or neo-classical scholars on the other hand, see the human being within the organization as the most important element for organizational efficiency. Accordingly, they consider the relationship between individuals and groups in organization as the focal point of analysis for organizational efficiency. 
In reality however, organizations consist of both structure and human beings. This means that their efficiency must be based on a balance between the two elements. Thus, modern writers on organization behavior seek to strike a balance between the two in analyzing organization efficiency.

All the above definitions present organization as purposeful, complex human activities, which are characterized by secondary or impersonal relationships, and sustained by co-operation. Organizations have specialized and limited goals, which form the basis of services and product provided to their environment. Organizations are composed of human beings who make use of non-human materials to provide needs for human satisfaction. And as living systems, organizations grow and diminish in growth, and as such can in the words of Amitai Etzioni (1964), be "constructed and reconstructed" to cope with environmental challenges. Organizations are also integrated within a large social system and consequently interact with the environment.

\section{Formal and Informal Organizations}

Organizations consist of two basic aspects-the formal and informal aspects. The formal organization can be referred to as the system of consciously designed structure of authority and pattern of official relationship among members whose behavior are coordinated through a body of legitimized rules and regulations, which give life and direction to the organization. This, in essence, presupposes the existence of officially identifiable lines of communication which define the relationship between the super-ordinate and subordinate and in the words of Herbert Simon (1976:148), determines "who may employ and fire whom, who will give order to whom, who is responsible for particular job and whose signature a particular type of decision must have". The structures so designed are occupied by officials who perform assigned responsibilities within the confines of the authority and power they are allowed to exercise. Any contrary behavior to the established rules of the organization attracts official sanction.

The formal organization also depicts formal groups (meetings, conferences, task forces, or committees) which are found in organizations and which according to Huczynski and Buchanan (1991:167) has the following characteristics:

1. They have formal structure;

2. They are task oriented;

3. They tend to be permanent;

4. Their activities contribute directly to the organization's collective purpose; and

5. They are consciously organized by somebody for a reason.

The informal organization on the other hand, "is a network of persons and social relations not established or required by the formal organization but arising spontaneously as people associate with one another" (Newstroni and Davis, 2002:286). As rightly observed by Chester Bernard (1948) that "when formal organizations come into operation, they create and require informal organization", and aptly supported by Herbert Simon (1976:149) that "each new organization member must have established informal relations with his colleagues before he 
becomes a significant part of the working organization", informal organizations are rather unconscious and planless relationship which are inevitable in formal organization.

Informal organization develops in many directions due to diverse nature of human interaction resulting into the emergence of different informal organizations in a formal organization. Informal organizations are not identifiable through formal organizational charts; neither are their emergence in formal organization anticipated or intended. They arise "during the spontaneous interaction of persons in the group as they talk, joke and associate with one another" (Huczynski and Buchanan 1991: 168). Because formal organization are rarely designed to satisfy employees' needs for love, affection and esteem, members unconsciously develop relationship which eventually lead to the formation of informal groups or informal organizations with the primary aim of realizing their personal ambitions while at work. According to Goel (2008:111), "informal organizations are the product of the complexity of the informal organization wherein employees found it difficult to satisfy their varied needs". Membership into a particular informal organization is by share desire for common social needs among members.

Even though, most managers/administrators will deny the existence of informal organization, their effects in a formal organization have been identified to include: (a) the establishment of certain attitudes, understanding, customs, habits, institutions; and (b) the creation of the condition under which formal organization may arise.

\section{Research Methodology}

The study made use of secondary source of data obtained through literature survey method. Literatures on Fredrick Taylor's Scientific Management Theory were purposefully selected for analyses. The essence of using secondary data was to sample opinions of writers in getting relevant information pertinent to the study. Data were analysed using content analysis.

\section{Taylor and the Scientific Management Theory}

The scientific management is the third strand of the classical theory of organization. Frederick Winslow Taylor (1856-1915), an American and the father of scientific management, as he is generally called 'was the first to give an adequate, complete explanation of scientific management'. His followers who wrote extensively on issues raised by him later developed his work. This however does not suggest that Taylor originated the idea. Taylor himself consented to this:

I do not believe that there is any man connected with Scientific Management who has the slightest pride of authorship in connection with it. Every one of us realizes that this has been the work of 100 men or more, and that work which anyone of us may have done is but a small fraction of the whole (Taylor, 1911).

Born in Philadelphia in 1856, Taylor became an apprentice mechanist in a firm of engineers after which he joined the Midrale Steel Company in 1878 where he rose to the rank of shop superintendent. It was while in this company that his ideas on scientific management were developed. Taylor was not particularly concerned with the study of organization parse, rather 
he concentrated on the incentive analysis of work process at the level of individual worker, and his main concern was with the individual worker and his job. From his experiment, he came up with what he referred to as "one best way".

Taylor's reaction was a challenge to disorder that he observed in typical plant of his days. Here the workers instead of being managed were managing themselves. Workers decided what work methods to be followed and selected their own tools for each operation. Taylor felt the need for standard work procedures, discovered and prescribed for them by the management instead of each workman using rule of thumb methods. This Taylor referred to as "traditional" knowledge as opposed to true science. Taylor's reaction to 'traditional' knowledge is thus stated:

......Now, among the various methods and implements used in each trade there is always one method and one implement which is quicker and better than any of the rest. And this one best method and best implement can only be discovered or developed through a scientific study and analysis of all the methods and implements in use, together with accurate, minute, motion and time study. In almost all of the mechanic arts the science which underlies each workman who is best suited to actually doing the work is incapable of fully understanding this science, without the guidance and help of those who are with him or over him either through lack of education or through insufficient mental capacity. Those in the management whose duty it is to develop this science should also guide and help the workman in working under it, and should assume a much larger share of the responsibility for results than under usual conditions is assumed by the management. (Taylor, 1911).

Taylor preferred a friendly co-operation between management and workers. In order to satisfy workers' demands and employers need, Taylor suggested a higher wages and differential piece rates for workers. This he believed will enhance maximum and quality output and reduce cost of labour to satisfy employer's needs. Thus, Taylor disregards the importance of collective bargaining between workers and management and argues that differential piece - rates would remove almost all causes of disputes and disagreements between workers and management. According to Taylor, "What constitutes a fair day's work will be a question of scientific investigation, instead of subject to be bargained and haggled over".

Taylor's idea can be summarized thus:

1. That the tasks of planning a job should be given to the management while that of doing the job should be given to the workers.

2. That the productivity of the organization requires productive workers, who understand the work process. Hence, workers must be scientifically selected on the basis of their fitness rather than on the basis of personal influence or friendship.

3. That the process or method of doing any work can be studied and mastered.

4. That of all the possible ways of doing one work, there is always one best way of doing it.

5. That once the one best method is known, master it and teach it to everybody who contribute to that process.

6. Having done that, compensate workers with adequate remuneration and strike a balance between workers' output and remuneration with strict supervision. 
7. When these are done, you get the best effectiveness and utmost productivity. Thus, there will be harmony of interest between workers and employers.

\section{Taylor's Objective and Practical Experiments}

Because Taylor wrote at a time of industrial unrest, disorder and sharp disagreement between workers and employers, he was primarily concerned about restoring order and ensuring greater harmony between workers and employers. Taylor was therefore confronted with the paradox of marrying the interests of workers and employers. "Taylor was appalled by what he regarded as the inefficiency of industrial practice and set out to show how management and workforce could mutually benefit by adopting his approach" (Huczynski and Buchanan 1991:282). He sought for reasons why workers revolt and found solution in high wages. "A mentally sluggish type" he states unequivocally that it is "high wages which he wants". On the part of employers, Taylor felt that a reduced labour force could enhance effectiveness and reduce cost. The workers' salary can thus be increased with the extra cost saved. According to him;

What workers most want, namely, high wages and the employers what they most want namely the maximum output and the best quality of work, which, means a low labour cost, (Taylor, 1911).

Taylor's specific objectives according to Huczynski and Buchanan (1985:283) were to achieve the following:

1. Efficiency, by increasing the output per worker and reducing deliberate 'underworking' by employees,

2. Standardization of job performance, by dividing tasks up into small and closely specified subtasks,

3. Discipline, by establishing hierarchical authority and introducing a system whereby all management's policy decisions could be implemented.

Taylor's reported the success of the application of scientific management to inspection of balls for bearing as a result of reduction of labour force from 120 to 35 workmen. A recorded improvement of about two-third of work quality was realized. Similar successes were witnessed when applied to shoveling, bricklaying, metal cutting and Pig-Iron handling. He suggested that a workman pay should be 30 to 100 percent above his earlier pay. Taylor's application of scientific management to shoveling for instance includes the following principles:

1. Select suitable job for study which has sufficient variety without being complex, which employs enough men to be worthwhile and would provide an object lesson to all when installed.

2. Select two good steady workers.

3. Time their actions.

4. Get them to use large shovels on heavy material. Total amount within a set time period is weighed and recorded. 
5. Shovel size reduced to that weight of shovel-load is decreased, but total amount shoveled per day rises.

6. Determine best weight per shovel-load, identity correct size of shovel for all other materials handled.

7. Study actual movement of arms and legs.

8. Produce 'science of shoveling' which shows correct method for each material and amount which should be shoveled per day by a first-class man. (Huczynski \& Buchanan, 1985, p. 284).

Taylor's motion-and-time studies have as an implied objective the reduction of 'soldiering'. Soldering according to Taylor is found everywhere, and they are of two types - natural and systematic. Natural soldering occurs when man intentionally does his work at pace so as not to overwork himself and conserves energy as against fatigue. This is strictly personal. The systematic soldering is more complex and it revolves around the individual, organization and society. It aimed at keeping the supervisor completely ignorant of how much work the workers can do so that the supervisor does not raise the work load or expect an increase, the consequence of which workers will have to work harder to earn the same old pay. This may also lead to situation whereby some workers will be relieved of their job.

The principle that codifies Taylor's Scientific Management include:

- Science, not rule of thumb.

- Harmony, not discord.

- Co-operation, not individualism.

- Maximum output, in place of restricted output.

- The development of each man to his greatest.

- Efficiency and prosperity.

\section{Criticism of Taylor's Scientific Management Theory}

The $21^{\text {st }}$ century organization, no doubt, has undergone tremendous transformation from what it was when Fredrick Taylor postulated the scientific management theory. Scholars like Warren Bennis (1973) for instance, took cognizance of these changes in emerging organizations before predicting that a more dynamic organization structure which he called the "organic-adaptive structure" will soon replace the programic and mechanically inclined structure of the early $20^{\text {th }}$ century organizations. Bennis (1973) argues that many factors, including the work values, organization's tasks and goals, motivation techniques and leadership styles, will accelerate the transformation of the $20^{\text {th }}$ century organization into the organic-adaptive nature. Consequent upon these and despite the remarkable success of scientific management in organizations where applied, Fredrick Taylor's invention has been criticized on several grounds, and thus castigated as unsuitable for the $21^{\text {st }}$ century organizations. The shortcomings of Taylor's scientific management theory include, among others, the following: 
1. Implicit in Taylor's recommendations is the recognition of a narrow span of control with each superior having not more than 6 subordinates. This suggests an organization with a very tall structure. Besides of the tallness of the organization, information flow is slow. Order flows from the above to various levels of supervision. This may lead to inappropriate information, distortion and inefficiency. Modern organisations encourage free flow of information and flat organization structure.

2. Taylor's supervision method implies that the superior must sit on the shoulders of his subordinates before they work. This is a fallacy, if acted upon could be counterproductive; it could elicit conflict between the superior and workers. Besides, the superior that must sit on the shoulders of his subordinates will have absolutely nothing to do than to supervise. There is little or no trust between workers and supervisors, and lack of initiative on the part of the workers. Furthermore, rather than focusing on individual efforts through breaking down of tasks into tiny steps as envisaged by Taylor Modern organization encourage team work which gives room for holistic evaluation of the entire work process for efficiency and maximum productivity.

3. Taylor assumes a stable environment. That the organization is closed and no infusion from outside is not true because the organization always react to its environment, which in most cases is dynamic. When an organization losses balance with the society it collapses. There is no totally closed organization.

4. Taylor's separation of the work force into two - the worker and the manager assumes of an all knowing manager or leader who must determine what have to be done and how to do it, while the worker obey automatically without question. The workman is no more than a slave in the production process. All he deserves at the end of the day is a "high wage". The workman is seen as machine, which has to be used and dropped when the need arises.

Besides, Taylor's scientific management Theory assumption that there is 'one night way' of doing something is anti-thetical to $21^{\text {st }}$ century management tools like management by objective (MBO), Business Process Reengineering (BPR) and other similar tools which are more effective and dynamic.

1. Taylor's motivation paradox is defective. That wages alone will sufficiently motivate workers to put in their best is a fallacy. Further studies carried out on motivation had shown that money alone is not sufficient to induce hard work. Taylor wrongly assumed an 'economic man' who must work for salary increase.

2. Taylor's differential piece-rate system where workers are paid a low piece-rate, up to the standard at which a first-class man performance is realized did not receive wide acceptability in management circle. At the standard, a large bonus is paid, and above standard, a higher piece rate is paid. The emphasis is on the first-class man.

3. Taylor's idea suggests a situation where authority is over-centralized. There are situations where centralization may be unproductive. Managers are to use their initiatives to avoid this. Modern organizations have undergone so much transformation for greater speed, efficiency and flexibility. Participative management and empowerment are fast taking over from command-and-control management.

4. Taylor's emphasis on a first-class man does not take into consideration the plight of less able workers, who may not be able to meet up with Taylor's accepted standard. Only 
first-class workers according to Taylor should be given employment while others remained redundant.

\section{Concluding Remarks}

Despite the above criticism of Taylor's Scientific Management, one cannot totally dismiss his idea, but acknowledge his immense contributions to management practice including his contributions to motivation theory and management techniques. Taylor's motivation paradox for instance include the following:

a. His idea of close supervision can encourage workers to work at their best.

b. Central to Taylor's idea is the importance of training. Workers must be taught one best way of doing a job.

c. His piece - rate system recommends remuneration according to contribution.

Apart from Taylor's motivation paradox, his contributions to techniques in management include "motion-and-time study, specialization, standardization, planning, work standard, piece-rate wage system". Ultimately, Taylor's emphasis of scientifism in organization management propelled the discovery of short-cut method and sophisticated modern management tools like job analysis, work studies and time and motion studies in accomplishing jobs in organizations. However, modern organizations have become more dynamic and required highly sophisticated management tools which were not envisaged by Taylor's scientific management theory.

\section{References}

Barnard, C. (1948). Organization and Management: Selected Papers. Harvard University Press.

Bennis, W. (1973). Beyond Bureaucracy. MC Graw Hill Higher Education: USA.

Eaus, J. M. (1936). The Frontiers of Public Administration. Dimock. Chicago, University of Chicago Press.

Etzioni (1964). Readings on Modern Organizations. New Jersey: Prentice-Hall, Inc.

Fayol, H (1949). General and Industrial Management. London: Pitman.

Gaus, J. M. (1947). Reflection on Public Administration._University of Alabama Press.

Gladden, E. N. (1962). Essentials of Public Administration. Staples Press.

Goel, S. L (2008). Advanced Public Administration. New Delhi: Deep \& Deep Publications PVT. Ltd in Gullick, L and Urwick, L (eds) Papers on the Science of Administration

Gullick, L (1937). Notes on the Theory of Organization. New York: Institute of Public Administration, Columbia University.

Huczynski, A., \& Buchanan, D. (1991). Organizational Behaviour: An Introductory Text (2nd ed.). New York: Prentice-Hall. 


\section{Macrothink}

Journal of Public Management Research

ISSN 2377-3294 2019, Vol. 5, No. 2

Koontz, H., \& O’Donnell, C. (1976). Management: A System and Contingency Analysis of Managerial Functions. New York: McGraw Hill.

Louis, A. (1958). Management and Organization. New York: McGraw-Hill.

Marx, F. M. (1946). Elements of Public Administration. New-Delhi: Prentice-Hall of India.

Mooney, J. D. (1947). The Principles of Organization. New York: Harper.

Newstrom, J., \& Davis K. (2002). Organizational Behaviour: Human Behaviour at Work. New Delhi: Tata McGraw-Hill Publishing Company Limited.

Pfiffner, J. M. (1960). Administrative Organization. New Jersey: Prentice-Hall. https://doi.org/10.2307/973965

Simon, H (1976). Administrative Behaviour: A Study of Decision-Making Process in Administrative Organizations. USA: McMillan Publishers.

Taylor, F. W. (1911). The Principles of Scientific Management. Harper and Row.

Tyagi, A. R. (2004). Public Administration: Principles and Practice. Delhi: Atma Ram \& Sons Publisher \& Booksellers.

\section{Copyright Disclaimer}

Copyright for this article is retained by the author(s), with first publication rights granted to the journal.

This is an open-access article distributed under the terms and conditions of the Creative Commons Attribution license (http://creativecommons.org/licenses/by/4.0/). 